UNIVERSITY OF CALIFORNIA

Radiation Laboratory

Contract No. W-7405-eng-48

Dechoseng

Californium Isotopes from Bombardment of Uranium with Carbon Ions

A. Ghiorso, S. G. Thompson, K. Street, Jr., and G. T. Seaborg

September 6, 1950

This cocument CAUTION Jnformat affeceng the

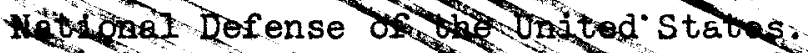

Its ransmission or tholosure of as endont in

any manner to an unauthorted Feroo is prov togend

may $r \in$ sult in severe criminal outies under a toble Federal Laws.

Berkeley, California 
UCRL-895

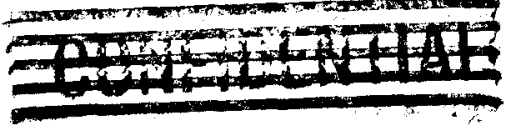

Argonne National Laboratory

$1=10$

Atomic Energy Commission, Washington

$11-12$

Brookhaven National Laboratory

$13-16$

Carbide and Carbon Chemicals Division ( $\mathrm{K}-25$ Plant)

$17-18$

Carbide and Carbon Chemicals Division ( $\mathrm{Y}-12$ Flant)

19

General Electric Company, Richland

Eanford Operations office

$20-25$

Iowa State College

26

27

Kellex Corporation

28

Knolls Atomic Power Laboratory

29-32

Los 4 lamos

$33-35$

Misund Laboratory

Naval Radiological Defense Laboratory

$36-38$

NEPA Project

39

New York Operations Office

40

Oak Ridge National Laboratory

$41-42$

Patent Branch, Washington

$43-48$

Technical Information Division, ORE

49

UCLA Medical Research Laboratory (Warren)

$50-64$

University of California Radiation Laboratory

65

University of Rochester

$66-68$

$59-70$

Total

70

Information Division

Radiation Laboratory

Univexsity of California

Berkeley, California 


\section{CALIFORNIUM ISOTOPES FROM BOMBARDMENT OF URANIUM WITH CARBON IONS}

\section{A. Ghiorso, S. G. Thompson, K. Street, Jr., and G. T. Seaborg Radiation Laboratory and Department of Chemistry University of California, Berkeley, California}

September 6, 1950

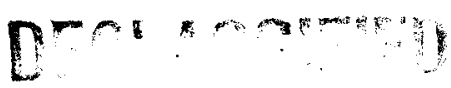

The recent production and identification ${ }^{1}$ of isotopes of elements with atomic numbers up to six higher than the target element through bombardment with hexapositive 120-Mev carbon ions made it seem worthwile to apply this technique to the transuranium region.

Accordingly, small pieces of natural uranium metal (about 0.5 mil thick and $2.5 \mathrm{~cm}$ by $0.6 \mathrm{~cm}$ area) were irradiated in the internal carbon ion beam in the Berkeley 60-inch cyclotron. Following the irradiations, the uranium was dissolved in dilute hydrochloric acid containing hydrogen peroxide and a transplutonium fraction was isolated through the use of lanthanum fluoride, and lanthanum hydroxide precipitation steps followed by the ion exchange adsorption column procedure in which concentrated hydrochloric acid is used to separate the tripositive actinide elements from the rare earth elements. 2

The transplutonium fractions in hydrochloric acid were evaporated as weightless films on platinum plates which were placed in the ionization chamber of the 48 channel pulse analyzer apparatus in order to measure the yield and energies of any alpha-particles which might be present. In the best experiment at about one hour after the end of the 90-minute bombardment, some 50 disintegrations per minute of the distinctive 7.1-Mev alpha-particles ${ }^{3}$ of $\mathrm{Cf}^{2 / 4}$ were observed to be present and to decay with the 45-minute half-life. The $\mathrm{Cf}^{244}$ was presumably formed by the reaction $\mathrm{U}^{238}\left(\mathrm{C}^{12}, 6 \mathrm{n}\right)$.

After the decay of the alpha-particles due to $\mathrm{Cf}^{244}$, about five disintegrations per minute of alpha-particles with $6.8-\mathrm{Mev}$ energy was observed and 
this alpha-radioactivity decayed with a halfolife of about 35 hours. A consideration of the systematics of alpha-radioactivity ${ }^{4}$ leads us to the riew that this activity is due to the new isotope $C f^{246}$ formed by the reaction $\mathrm{U}^{238}\left(\mathrm{C}^{12}, 4 \mathrm{n}\right)$. The measured half-life agrees with the expected alpha hali-life for the observed energy for an even-even isotope of the element with atomic number 98 .

It is not possible at this time to obtain a good estimate of the intensity of the carbon ion bearil. Therefore, the cross sections for the reactions given above cannot be caiculated. However, it is interesting to note that the indicated yields for the $(C, 6 n)$ and $(C, 4 n)$ reactions are comparabie.

If the isotopic assignment of the new 35 -hour activity to cif 246 is correct, these new data give a better idea as to the slope of the alpha-energy v5. mass number line for californium, which in turn makes it possibie to make betrer predictions of the radicactive properties of the nuclides in this region.

We wish to express our appreciation to Professor J.G. Hamilton, J.F゙。 Miller, G. B. Rossi, $\mathrm{I}, \mathrm{M}$ 。 Putnam, Jro, M。 $\mathrm{T}$ 。Webb, and the operating orew of the 60-inch cyciotron in the Crocker Laboratory for their help in the carbon ion bombardments. We would also like to thank $\mathrm{Mr}$ 。 $E$. $K$. Hulet for his help in the chemical separations. This work was performed under the auspices of the U. S. Atomic Energy Commission.

${ }^{1}$ Miller, Hamilton, Putnam, Haymond, and Rossi, Phys。 Rev (in press).

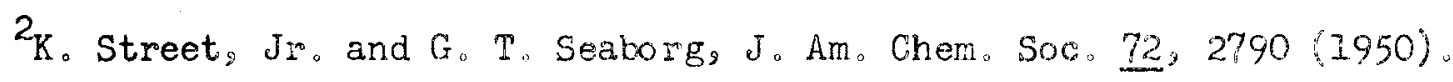

${ }^{3}$ Thompson, Street, Iro, Ghiorso, ard Seaborg, Phys。 Fev。 78, 298 (1950).

4 Perlman, Ghiorso, and Seaborg, Phys. Rev, 7?, 26 (2950) 